https://doi.org/10.3126/pragya.v7i1.35250

\title{
Home-Based Workers and their Ownership in Nepal
}

Sah Badri Narayan, PhD

\begin{abstract}
Hom- based workers are the most significant component of informal economy in Nepal. In Nepal, 70 percent of the economically active population is involved in the informal economy. Employment in the non-agricultural informal sector is 70 percent of total non-agricultural employment. The employed population in the non-agricultural sectors grew by 29.3 percent. About 30 percent of the non-agricultural workers aged 15 and above are home based workers and home based work is the major source of employment for women. The share of non-agriculture sector to GDP is highly increasing in recent years; its average annual growth is 7.4 percent in 2018/19. In this study, more than 76 percent of home based workers are from Tribal/Native/Adibasi ethnicity. Also the 76 percent home based workers have their own house as ownership. The 86 percent of home based workers have houses with well window facilities and 99 percent of the housesare facilitated with electricity, 41 percent of the households have source of water, 30 percent to hand pumpand 6 percent to wells. The 95 percent of home based workers have latrine facilities in their house. The income earned is highly spent on food expenses (54 percent) and remaining is used for other purposes.
\end{abstract}

Keywords: Informal Economy, Home Based Workers, Enterprises, Female Workers, Ownership.

\section{Introduction}

The world economy growth rate was 3.6 percent in 2018, 2.9 percent in 2019 and the economic growth rate in 2020 is expected to shrink to 3.0 percent. The developed economy growth rate was 2.2 percent in 2018, 1.7percent in 2019 and the economic growth rate in 2020 is expected to shrink to 6.1 percent. Similarly, minimum income leveldeveloping countries growthrate was 5.1 percent in 2018, 5.1 percent in 2019 and estimated to be 0.4 percent in 2020. Nepal's economy growth rate was 6.7 percent in 2018, 7.1 percent in 2019 and estimated to be 2.5 percent in 2020. The contribution of the non-agricultural sector and agricultural sector to GDP in 2019/20 is 72.4 percent and 27.6 percent respectively. While the contribution to the total GDP of the country from non-agricultural and agricultural sector was 72.5 percent and 27.5 percent in 2018/19. Besides, the primary sector, secondary sector and third sector economic growth rates are 2.5 percent, 3.4 percent and 2.0 percent respectively. Also, the contribution from these sectors to the GDP of the country is assumed to be 28.2, 13.7 and 58.1 percent respectively. The absolute poverty was 18.7 percent in 
$2017 / 18$ which is estimated to be around 16.7 percent in $2019 / 20$. The per capita income increased in GDP from US \$1039 in the year 2018/19 to US \$1085 in the year 2019/20. This increase took place by 7.5 percent (MOF 2019/20). Recently, the economy got heavily affected due to the outbreak of the corona virus (COVID-19) pandemic in 2020.

The share of non-agricultural sector to GDP is highly increasing in recent years. Its average annual growth was 7.7 percent in 2017/18, 7.4 percent in 2018/19 and assumed to be 2.3 percent in 2019/20. There aremore than 70 percent of the economically active population involved in the informal economy of Nepal and the informal sector accounts for 70 to 80 percent of Nepal's total employment in the non-agricultural sector (NLFS 2008). Home based workers are the most significant component of informal economy in Nepal. The number of home based workers is estimated to be around 2.2 million of which 78 percent are women.In this way, home based workers are the most valuable component of informal economy and play's a vital role in Nepalese economy.

Almost 50 percent of the home based workers earn less than Rs. 2,000 from home based works and less than 15 percent of home based workers earn more than 5,000 rupees from home works (HNN 2011). Involvement of Nepalese population in this sector is very high. Economy of Nepal is a combination of formal and informal economy as a whole. The share of informal economy is much higher in the national economy compared to formal economy. Informal economy significantly contributes toeconomic, social as well as human development of Nepal. Home based workers are one third of non-agricultural labour force of Nepal. The proportion of home- based women workers are much higher than men workers. Mostly rural people are involved in home based work for their livelihood. So the participation in home based worksis high in rural areas of Nepal. In Nepal, the women are mostly involved in inherited skills such as handloom, weaving, knitting, yarn-making and other traditional handicrafts.

The data below shows thepercentage of male, female and all non-agricultural home basedworkers from the neighbouring countries (Table 1).

Table 1: Percentages of male, female and all non-agricultural workers

\begin{tabular}{|l|c|c|c|}
\hline Country & Male & Female & All \\
\hline Bangladesh (2009) & 5.9 & 12.1 & 7.2 \\
\hline India (2011/12) & 11.0 & 31.7 & 15.2 \\
\hline Pakistan (2008/09) & 1.5 & 40.0 & 5.3 \\
\hline Nepal (2008) & 21.6 & 47.6 & 30.0 \\
\hline
\end{tabular}

Source: Home Based Workers and Cities, Martha A. Chen \& Shalini Sinha (downloaded from website, June 2, 2018). 
More than 70 percent of the economically active population is involved in the informal economy of Nepal. This sector is rapidly expanding due to change in employment patterns. A report published about 50 million home based workers estimated in South Asia among which 80 percent of them are women. A large number of women work as home based workers among the Asian countries in Pakistan. According to the World Bank study, over 10 million women are engaged in home based work and basically they are involved in garment, bangle-making, shoe stitching, embroidery, carpet and weaving etc.

\section{Definition of the Home Based Workers}

Home-based workers are defined as (i) workers working in their homes or at a workplace near their home (ii) workers carrying out work in their homes specified by the employer. They work under no written contract and work for an employer. There are cases where subcontractor, agent or middle men are present or the workers can be self employed or work for family enterprises. The nature of these workers reveal that they are self employed and some are sub-contracted. Most of the home based workers in Nepal still prefer to work in isolation in an invisible way. Thus, Home based works has provided a means of livelihood for many workers who are in poor economic condition and have less than employment opportunities in other sectors.

Moreover, home based workers produce goods and services for the market from within or around their own homes. They produce a wide range of low and high end goods and services for domestic as well as international markets. Recently, these workers represent a significant contribution of urban and semi urban employment of the country like Nepal.There are many types of home based works in Nepal, among these the main categories of home based worksare mentioned as follows;
1. Tailoring
6. Dhaka weaving
11. Handloom
2. Hand embroidery
7. Nepali shoe making
12. Yarn making
3. Knitting
8. Traditional
food
13. Packaging processing
4. Doll making
9. Beads work
14. Handicrafts
5. Wool spinning
10. Batekodhoop
15. Painting

In Nepal, several ethnicity group of home based workers are involved on that works shown by pie chart (Figure 1). 
Figure 1: Involvement of home based workers by ethnicity
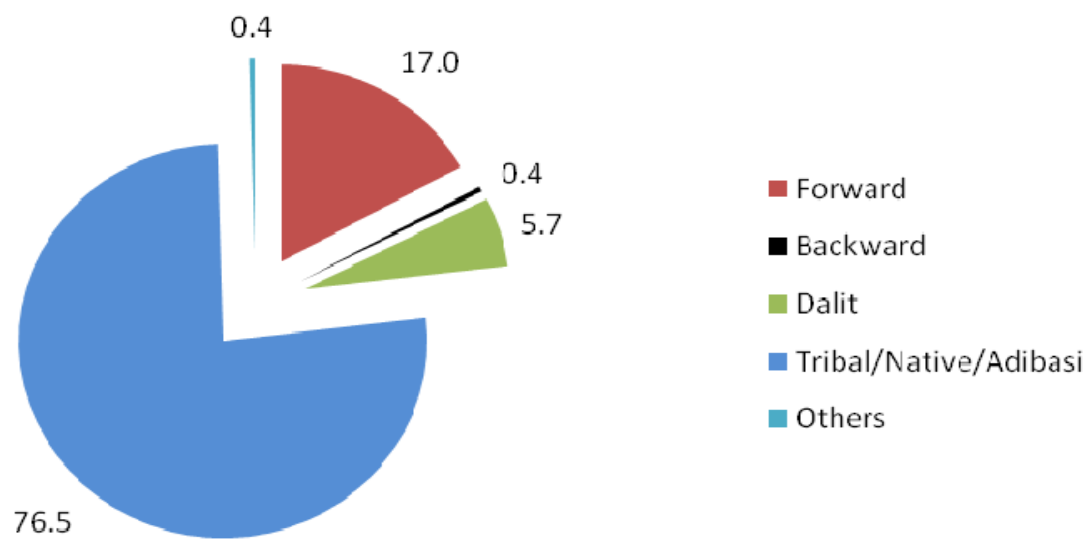

Source: Field survey 2014.

\section{Problems ofHome Based Workers}

Home based works in informal economy faces multiple challenges and constraints as follows;

- Home based workers often face lack of basic infrastructures facilities at home-cumwork places.

- Self employed ones basically face the problems of marketing, price, skill upgrading and low training opportunities.

- Workers are suffering from exploitation and are deprived of many fundamental rights at work.

- Home based workers suffering from limited knowledge of market and market prices because they work far from their own homes.

- Home based workers are isolated from other workers in their sectors.

- Home based workers are also suffering from the problems of irregular purchase, work order, irregular supply of raw materials including delaypayments.

- Home based workers average earnings are not only low but also erratic due to seasonal environment.

- Occupational health and safety is a critical issue for home based workers. There is absence of good health safety facility for them.

- Home based workers are forced to work in candle light due to frequent light cut problem. So the dim light affects their eyes and irritates the nose including throat problems. 
- The contribution of home based workers to the economy remains largely invisible and undervalued.

- Particularly true for women who represent the majority of home based workers.

- Sub contracted home based workers law is not covered under labour or employment law.

- Self employed home based workers are not covered by commercial law regulating contracts and transactions.

- Lack of appropriate rule and regulations including government policies for home based workers.

\section{Review of Literature}

WIEGO (2012) examined the definitional, theoretical and policy related overview on the informal economy. The study also examined the linkages between the informal economy formal firmsand formal regulations and formalized the debate on informal economy. There are six parts of the study; (i) a brief historical overview of the informal sector (ii) summary of the recent rethinking concept including the expanded concept of informal employment (iii) the linkages between the informal economy formal firms and formal regulations (iv) policy responses to the informal economy including the formalization of debate (v) comprehensive policy approach and (vi) the future of informality. The study provided a comprehensive policy response to the informal economy with four pillars (i) create more formal jobs (ii) regulate informal enterprises and informal jobs (iii) extend state protection (social and legal) and (iv) increase the productivity of informal enterprises and the income of informal workers.So, the study focused on the relevant authorities of the countries required to formulate appropriate conductive policies in order to encourage home based workers in informal economy.

HNN (2011) stressed the economy of Nepal is combination of formal and informal economies in general. The share of informal economy is much higher in the national economy compared to formal economy. Both economies are interdependent to each other. Informal economy is unregulated, unrecognized, unstructured and also subordinate. Informal economy is dependent upon the feature of capitalist economy and globalization. Home based works provided a means of livelihood for many workers, poor people who have less employment opportunities in other sectors. The study shows that almost 50 percent of the homebased workers monthly income generated from homebased works is less than NPR 2,000 and the percentage of home based workers earning more than NPR 5,000 per month is less than 15 percent. The study also focused that there are several areas for the intervention of government and local authorities to improve the livelihood of the home based workers. 
Donna L. Doane (2007) highlighted the relationship between home based work and persistent poverty in certain parts of South and South East Asia. The study also highlighted on the question of inter generational poverty in the families of home based workers and the possibility of using social protection and other related policies which helps to alleviate poverty and vulnerability. Similarly, the study elaborated wide range of issues, including an analysis of specific indigenousgroups, local, national and social protection scheme. There is influence of such considerations on local cultures and religious activities. The study indicated that the formal social protection schemes are generally not available to deal with there risks and reversals. The home based workers earnings are usually too low and irregular to be able to join. They mostly rely on relatives, friends and community members. Therefore, this type of local support system can be very important to the home based workers.

ILO (2004) investigated a wide range of overview related to the characteristics of Nepal's informal economy. The study focuses in terms of demographics, labour relations, and decent work deficits. There is no guarantee of economic and social security of home based workers. The study shows that home based workers are the fastest growing and least protected. The study also expressed that there is absence of social and employment security arrangement for informal workers. Also, for employers there is no market and enterprise security. There are more enforcement gaps than legislation gaps.There was guarantee for home based workers minimum wages and also ensuring a system for fair wages based on their skill and productivity. Moreover, enterprises development and promotion of entrepreneurship is needed with basic emphasis on micro enterprises.

Chapagain (2000) focused on contract labour in Nepal. In Nepal, the contract labour is found basically in three forms; (i) 'karar' a fix time contract) (ii) 'thekka' a fix job contract and (iii) 'piece-rate' wages fixed as per production. Similarly there are two types of contract labour; (a) the indirect contracting and (b) the direct contracting. Contracting works can be classified in two different types (i) contracting for employment only and (ii) contracting for commercial purpose. Basically all home based workers come through contract labour. The main role is to assist in the growth of home based products that can be exported in theinternational market. Majority of the home based workers work in the informal sector but they are suffering from the absence of related laws, rules and regulations and facing practical problems. Therefore, the study stressed on the preparation of the action programme for the future to cope with the problems of inequality being created between regular and contract labour.

\section{Objectives of the Study}

The main objectives of the study are;

- $\quad$ To find out the basic problems of home based workers in Nepal. 
- $\quad$ To focus on the ownership of the home based workers in Nepal.

\section{Methodology}

The study depends upon the primary as well as secondary sources of data and information. In which available data from a study survey conducted in various places of urban as well as semi urban areas in Kathmandu and Bhaktapur districts of Nepal are used in the research. The sample size of the study is 96 in Kathmandu and380 in Bhaktapur.Sothe primarysources of information arecollected by directly interviewing the home based workers. Secondary sources of information are mainly publications from newspapers, books, journal including reports published by national and international organizations. Besides, the internet is also used as secondary sources of information. All sources of data and information are used for the research analysis on the heading of "Home Based Workers and their Ownership in Nepal”.

\section{Data Analysis}

Ownership is the important part of the home based workers and it is an essential productive asset for them. In this context, home based workers; whose home is their workplace is apositive aspect which increasesthe quality and productivity of goods. In this study, the classification of home based workers having own house as their ownership is in high rank (76 percent). A large percentage of home based workers have reported of having self own house in Bhaktapur (78 percent) and Kathmandu (66 percent). However, home based workers have their own house as ownership in significant ways.Similarly, classification as rented in 18 percent, government quarter in 3 percent, relative house in 2 percent and owned by family in 1 percent (Table $2 \&$ Figure 2 ).

Table 2: Classification of home based workers having own house

\begin{tabular}{|l|r|r|r|r|r|r|}
\hline \multirow{2}{*}{ Ownership } & \multicolumn{2}{|c|}{ Bhaktapur } & \multicolumn{2}{c|}{ Kathmandu } & \multicolumn{2}{c|}{ Total } \\
\cline { 2 - 7 } & \multicolumn{1}{|c|}{ No. } & \multicolumn{1}{c|}{$\%$} & \multicolumn{1}{c|}{ No. } & \multicolumn{1}{c|}{$\%$} & No. & \multicolumn{1}{c|}{$\%$} \\
\hline 1. Self owned & 298 & 78.4 & 63 & 65.6 & 361 & 75.8 \\
\hline 2. Owned by family & 6 & 1.6 & & 0.0 & 6 & 1.3 \\
\hline 3. Rented & 69 & 18.2 & 17 & 17.7 & 86 & 18.1 \\
\hline 4. Govt. house/quarter & 1 & 0.3 & 13 & 13.5 & 14 & 2.9 \\
\hline 5. Relatives house & 6 & 1.6 & 3 & 3.1 & 9 & 1.9 \\
\hline Total & 380 & 100.0 & 96 & 100.0 & 476 & 100.0 \\
\hline
\end{tabular}

Source: Field Survey 2014. 
House type of home based workers in Kathmandu home based workers have temporary (kachha), semi pakka and permanent (pakka) is 18 percent, 49 percent and 33 percent respectively. Similarlyin same type of house in Bhaktapur home based workers have 13 percent, 46 percent and 40 percent (Table 3).

Table 3 : House type of home based workers

\begin{tabular}{|l|r|r|r|r|r|r|}
\hline \multirow{2}{*}{ House } & \multicolumn{2}{|c|}{ Bhaktapur } & \multicolumn{2}{c|}{ Kathmandu } & \multicolumn{2}{c|}{ Total } \\
\cline { 2 - 7 } & \multicolumn{1}{|c|}{ No. } & \multicolumn{1}{c|}{$\%$} & \multicolumn{1}{c|}{ No. } & \multicolumn{1}{c|}{$\%$} & \multicolumn{1}{c|}{ No. } & \multicolumn{1}{c|}{$\%$} \\
\hline 1. Temporary (kachha) & 51 & 13.4 & 17 & 17.7 & 68 & 14.3 \\
\hline 2. Semi pakka & 176 & 46.3 & 47 & 49.0 & 223 & 46.8 \\
\hline 3. Parmanent (pakka) & 153 & 40.3 & 32 & 33.3 & 185 & 38.9 \\
\hline Total & 380 & 100.0 & 96 & 100.0 & 476 & 100.0 \\
\hline
\end{tabular}

Source: Field Survey 2014.

Figuire 2: Distribution of home based workers having own house

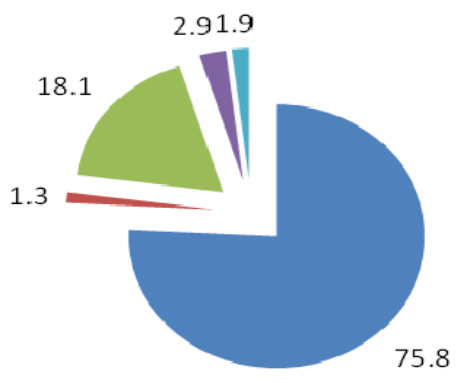

$$
\begin{aligned}
& \text { - Self owned } \\
& \text { - Owned by family } \\
& \text { - Rented } \\
& \text { - Govt house/quarter } \\
& \text { - Relatives house }
\end{aligned}
$$

Source: Field Survey 2014.

Relatively large percentages of home based workers have reported of having their own house and have window in their house. The 86 percent home based workers have reported that their house have windows facilities. But 14 percent of home based workers have reported that their house have no windows (Table 4).

\section{Table 4: Home based workers house have windows}

\begin{tabular}{|l|r|r|r|r|r|r|}
\hline \multirow{2}{*}{ Window } & \multicolumn{2}{|c|}{ Bhaktapur } & \multicolumn{2}{c|}{ Kathmandu } & \multicolumn{2}{c|}{ Total } \\
\cline { 2 - 8 } & No. & \multicolumn{1}{c|}{$\%$} & No. & \multicolumn{1}{c|}{$\%$} & \multicolumn{1}{c|}{ No. } & \multicolumn{1}{c|}{$\%$} \\
\hline 1. Yes & 332 & 87.4 & 77 & 80.2 & 409 & 85.9 \\
\hline 2. No & 48 & 12.6 & 19 & 19.8 & 67 & 14.1 \\
\hline Total & 380 & 100.0 & 96 & 100.0 & 476 & 100.0 \\
\hline
\end{tabular}

Source: Field Survey 2014. 
About 99 percent of home based workers house is connected with the electricity facility. Butone percent of home based workers reported of having no electricity facility (Table 5).

Table 5: Electricity connection of home based workers house

\begin{tabular}{|l|r|r|r|r|r|r|}
\hline \multirow{2}{*}{ Electricity } & \multicolumn{2}{|c|}{ Bhaktapur } & \multicolumn{2}{c|}{ Kathmandu } & \multicolumn{2}{c|}{ Total } \\
\cline { 2 - 7 } & \multicolumn{1}{|c}{ No. } & \multicolumn{1}{c|}{$\%$} & \multicolumn{1}{c|}{ No. } & \multicolumn{1}{c|}{$\%$} & \multicolumn{1}{c|}{ No. } & \multicolumn{1}{c|}{$\%$} \\
\hline 1. Yes & 377 & 99.2 & 94 & 97.9 & 471 & 98.9 \\
\hline 2. No & 3 & 0.8 & 2 & 2.1 & 5 & 1.1 \\
\hline Total & 380 & 100.0 & 96 & 100.0 & 476 & 100.0 \\
\hline
\end{tabular}

Source: Field Survey 2014.

Information on types of fuel uses for cooking, the higher percentage of home based workers reported of usinggas in kitchen (97 percent). A lowest percentage of home based workers have used electricity and wood for cooking (Table 6).

Table 6: Types of fuel uses for cooking by home based workers

\begin{tabular}{|l|r|r|r|r|r|r|}
\hline \multirow{2}{*}{ Fuel type } & \multicolumn{2}{|c|}{ Bhaktapur } & \multicolumn{2}{c|}{ Kathmandu } & \multicolumn{2}{c|}{ Total } \\
\cline { 2 - 7 } & No. & \multicolumn{1}{c|}{$\%$} & No. & \multicolumn{1}{c|}{$\%$} & No. & \multicolumn{1}{c|}{$\%$} \\
\hline 1. Gas & 368 & 96.8 & 92 & 95.8 & 460 & 96.6 \\
\hline 2. Electricity & 1 & 0.3 & 1 & 1.0 & 2 & 0.4 \\
\hline 3.Wood & 10 & 2.6 & 3 & 3.1 & 13 & 2.7 \\
\hline 4. Coal & 1 & 0.3 & & 0.0 & 1 & 0.2 \\
\hline Total & 380 & 100.0 & 96 & 100.0 & 476 & 100.0 \\
\hline
\end{tabular}

Source: Field Survey 2014.

Majority of home based workers ownership on source of water is own tap, own hand pump and own bore well in 41 percent, 30 percent and 6 percent respectively. Similarly small groups of home based workers use water by community hand pump, community tap and community bore well (Table 7).

Table 7: Source of water uses by home based workers

\begin{tabular}{|l|r|r|r|r|r|r|}
\hline \multirow{2}{*}{ Source of water } & \multicolumn{2}{|c|}{ Bhaktapur } & \multicolumn{2}{c|}{ Kathmandu } & \multicolumn{2}{c|}{ Total } \\
\cline { 2 - 7 } & No. & \multicolumn{1}{c|}{$\%$} & No. & \multicolumn{1}{c|}{$\%$} & \multicolumn{1}{c|}{ No. } & \multicolumn{1}{c|}{$\%$} \\
\hline 1. Own hand pump & 107 & 28.2 & 36 & 37.5 & 143 & 30.0 \\
\hline 2. Community hand pump & 36 & 9.5 & 4 & 4.2 & 40 & 8.4 \\
\hline 3. Own tap & 176 & 46.3 & 19 & 19.8 & 195 & 41.0 \\
\hline 4. Community tap & 27 & 7.1 & 12 & 12.5 & 39 & 8.2 \\
\hline 5. Own bore well & 23 & 6.1 & 4 & 4.2 & 27 & 5.7 \\
\hline 6. Community bore well & 11 & 2.9 & 21 & 21.9 & 32 & 6.7 \\
\hline Total & 380 & 100.0 & 96 & 100.0 & 476 & 100.0 \\
\hline
\end{tabular}


Source: Field Survey 2014.

Most of the home based workers reported that they have latrine facility in their own house (95 percent). Few percentages of home based workers use household latrine, public latrine and some go for open choice. (Table 8).

Table 8: Latrine facility uses by home based workers

\begin{tabular}{|l|r|r|r|r|r|r|}
\hline \multirow{2}{*}{ Latrine facility } & \multicolumn{2}{|c|}{ Bhaktapur } & \multicolumn{2}{c|}{ Kathmandu } & \multicolumn{2}{c|}{ Total } \\
\cline { 2 - 8 } & No. & \multicolumn{1}{c|}{$\%$} & \multicolumn{1}{c|}{ No. } & \multicolumn{1}{c|}{$\%$} & \multicolumn{1}{c|}{ No. } & \multicolumn{1}{c|}{$\%$} \\
\hline 1. Have in my house & 358 & 94.2 & 94 & 97.9 & 452 & 95.0 \\
\hline 2. Shared with household & 1 & 0.3 & 1 & 1.0 & 2 & 0.4 \\
\hline 3. Public & 12 & 3.2 & 1 & 1.0 & 13 & 2.7 \\
\hline 4. Non/open & 9 & 2.4 & & 0.0 & 9 & 1.9 \\
\hline Total & 380 & 100.0 & 96 & 100.0 & 476 & 100.0 \\
\hline
\end{tabular}

Source: Field Survey 2014.

The ownership on money the home based workers earn is very interesting. Generally, the home based workers spend their money on food expenses (54 percent). About 24 percent home based workers are reported to spend money on their children and 12 percent are reported to keep for themselves. The 5 percent of home based workers give money to their spouse and remaining 5 percent does saving. (Figure 3).

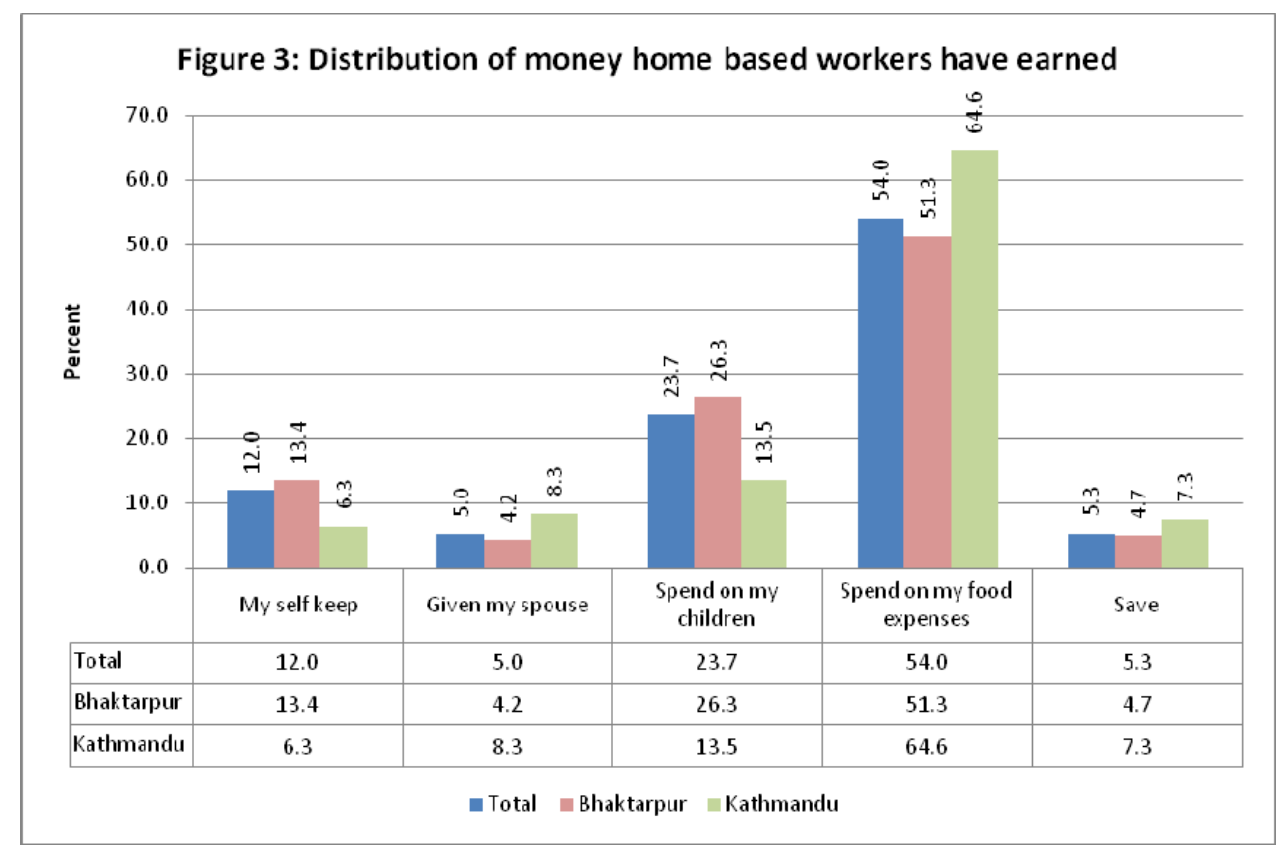

Source: Field Survey 2014. 


\section{Findings of the Study}

The major findings of the study are as follows;

* More than 76 percent of home based workers involvement is fromTribal/Native/Adibasi ethnicity and remaining few percentage participates from foreward, backward, dalit and others castes.

* Around 76 percent ofhome based workers have own house as their ownership and the remaining have rented which is 18 percent, government quarter is 3 percent, relative house is 2 percent and owned by family isone percent.

* Mostly home based workers have pakka (39 percent) and semi pakka (47 percent) house and only 14 percent have kachha house.

* The 86 percent of home based workers house have well windows facilities and 99 percent of home based workers house is connected with electricity.

* High percentage of home based workers use gas for cooking (97 percent).

* The home based workers ownership on source of water is tap which is 41 percent, own hand pump is 30 percent and own bore well is 6 percent.

* Almost 95 percent home based workers have toilet facility in their own house. Only 5percent use household latrine, public latrine and some go for open toilet.

* The ownership on earned money transactions is high in food expenses (54 percent) and 24 percent is spent on their children. Remaining 12 percent is kept for self, 5 percent given to their spouse and 5 percent is for saving.

* Home based workers;especially women contribute to the household budget and by working away from home, care of children and elderly to the quality of family life.

* Provide goods and services at a low cost to low income groups people and general public also.

* Besides, this occupational health and safety is a critical issue, high rent and lack of affordable housing for non-house workers is a major concern.

\section{Conclusion}

Nepal is poor and least developing countries in the world. Agriculture is the main occupation of the economy, providing a livelihood for two-thirds of the population in the country. But its contribution is only one-third of GDP. The contribution of non-agriculture sector is 73 percent to GDP in recent years.About70 percent of the economically active population of Nepal is involved in the informal economy. Employment in the nonagriculture informal sector is 70 percent of total non-agricultural employment.The employed population in the non-agriculture sector grew by 29.3 percent. About 30 percent of the nonagriculture worker aged 15 and above is home based workers and home based work is major 
source of employment for women. Approximately one-half of women non-agriculture workers in the country, specifically 47.6 percent home based workers compared to 21.6 of men. Highly informal employment is in non-agriculture sector of rural areas, which are 85.3 percent males and 93.5 percent females. Urban sector involvement of males is 80.7 percent and 88.9 percent females informally employed in non-agriculture sector (NLFS 2008).Highly female workers are involved than male workers in this sector of Nepal.

Ownership is the most important part of the home based workers which is essential productive asset for workers. But they are suffering from home cum workplace lack of basic infrastructure facilities. Many home based workers live in congested, low lying areas and areas far from the costumers, contractors and markets. Sometimes they stop work due to frequent cut electricity. Home based workers living in rent and pay very high rent. Home based workers also suffering from limited knowledge of market, market fair prices, fair price rate and protection of delay payments. In this connection, home based workers need to integrate home based workers and their livelihood activities into local economic development plans and improvement in all existing settlements and extend basic infrastructure to all homes and settlements. So government needs to recognize the informal sector home based workerscontribution in socio-economic development of Nepal. Moreover, integrate informal sector activities, upgrade policy and make favorable rules and regulations.

\section{References}

Arora R.C., (1986), Integrated Rural Development.

CBS. (2018), Nepal labour force survey 2017/18, Report on the Nepal LabourForce Survey (NLFS), Central Bureau of Statistics,National Planning Commission Secretariat, Government of Nepal.

, (2014), Population Monograph of Nepal, Volume I, II \& III, Central Bureau of Statistics, Kathmandu. Nepal.

, (2011), Nepal Living Standard Survey, Central Bureau of Statistics, Kathmandu. Nepal. , (2009), Nepal LabourForce Survey 2008, Statistical Report, National Planning Commission Secretariat, Government of Nepal.

, (2008), Nepal Labour Force Survey, Central Bureau of Statistics, Kathmandu. Nepal.

, (2005), Poverty Assessment Results (Briefing Notes Presented at a National Workshop on NLSS Results Held in May 2005).

Chapagain P. Dinesh (2000), Contract Labour in Nepal, Kathmandu, Nepal. 
Donna L. Doane (2007), Living in the Background Home Based Workers and Poverty Persistence, CPRC Working Paper 97.

HBWs (2018), Home Based Workers and Cities, Martha A. Chen and Shalini Sinha (website downloaded, June 2, 2018).

HNN (2011), Study on Urban Issues of Home Based Workers in Selected Cities of Nepal, Issues Based Study in Two Cities: Kathmandu Valley and Hetauda,Home Net Nepal, Kathmandu.

ILO (2004), The Informal Economy and Workers in Nepal, International Labour Organization, Kathmandu, Nepal.

MOF (2020), Economic Survey 2019/20, Ministry of Finance, Kathmandu. Nepal. , (2019), Economic Survey 2018/19, Ministry of Finance, Kathmandu. Nepal. , (2018), Economic Survey 2017/18, Ministry of Finance, Kathmandu. Nepal. (2017), Economic Survey 2016/17, Ministry of Finance, Kathmandu. Nepal.

MOLE (2014), Labour Migration for Employment, A Status Report for Nepal, Department of Foreign Employment, Ministry of Labour and Employment, Kathmandu, Nepal.

NRB (2019). Annual Report 2018/19, Nepal Rastra Bank, Kathmandu, Nepal

— (2017), Annual Reportand Quarterly Economic Bulletin (various issues) 2016/17, Nepal Rastra Bank, Kathmandu, Nepal. , (2012), Current Macro Economic Situation of Nepal, Nepal Rastra Bank, Kathmandu, Nepal.

Raveendran G. and Vanek J. (2013), Statistics on Home Based workers in Nepal.

Upadhyaya U. (2000), Home Based Workers in Nepal, South Asia Homnet Bulletin.

WIEGO (2012), The Informal Economy: Definitions, Theories and Policies, Women in Informal Employment Globalizing and Organizing.

WOOD J. John (2014), Home Based Jobs; Business Ideas Opportunities for Entrepreneurs. 